\title{
Preparing for a Successful Career in the Hospitality Industry
}

\author{
Kate Walsh, Michael C. Sturman, and Bill Carroll
}

If you have picked up this book, chances are good that you are either working in the hospitality industry or considering a hospitality position. Great choice! This chapter discusses you as a candidate for employment or advancement in the hospitality industry. Future chapters examine the many aspects of hospitality operations; but, so that you can develop your own competitive advantage, let's start with you. First, we offer a take at what companies are looking for from potential employees. Then, we switch the lens and review the changing nature of careers and what you should look for from a potential employer. We'll also touch on the differences between managing people and leading others-and then you can read more on this topic in Chapter 6. No industry offers better opportunities for you to move up into a leadership role, if you so desire, so we'll also look at leadership opportunities within this industry. Finally, we conclude with advice on what you can and should consider as you move into and up within the world's largest industry.

\section{Hospitality Career Opportunities}

The hospitality industry presents diverse career opportunities, and your prospects for a management position are excellent. Not only can you benefit from industry turnover, but most hotel chains have long-term expansion plans. Although the Great Recession slowed things down a bit, hospitality companies are constantly seeking outstanding talent. ${ }^{1}$ The thing you need to do to advance is to make sure that you offer the right "human capital." As explained in greater detail in Chapter 28, human capital refers to your present and future knowledge, skills, and abilities. ${ }^{2}$ It is intangible, but it is a critical resource that a company needs to build its competitive advantage. That is, it's the people that make a company profitable, and employees do this by applying their human capital directly and in concert with a company's physical assets - including buildings, equipment, and furnishings - to deliver the company's services. We'll provide an overview of the human capital you need to develop to take advantage of advancement opportunities, and then you can read more specifics about what you need to know in other chapters of this book. 
Industry Outlook

By almost any measure, the size of the hospitality labor market is large. Based on traditional economic and business perspectives, the size of the industry is measured by the scope of the hospitality market and the number of individuals employed in its organizations. Globally, the industry is estimated to employ 1 of every 15 workers. In the United States, the restaurant and hotel industries comprise over 328,000 management, business, and financial occupations. ${ }^{3}$ As large as the hospitality industry is, we should point out that hospitality industry employment includes not only working in hotels and restaurants, but also jobs in suppliers and other ancillary businesses, such as consulting, technology providers, and construction firms. In addition, you can find employment opportunities in other industries that have human capital requirements similar to hospitality. ${ }^{4}$ For example, health care providers have been recruiting hospitality managers to help them enhance their service aspects, and there is a growing interest in the long-term care industry to hire those regularly employed in the hospitality industry. Even grocery stores try to develop a service orientation similar to that of the hospitality industry. ${ }^{5}$

Your employment prospects in the hospitality industry are promising. In the United States alone, the federal Department of Commerce forecasts that the hospitality industry will grow at 5 percent annually through $2018 .{ }^{6}$ Growth will be even stronger in Asia, particularly in China and India. So you could definitely consider your opportunities for multinational careers (as discussed in Chapter 5). In short, absent another recession, if you have hospitality-based human capital, you should have excellent prospects, both in the hospitality industry and in its related businesses. Furthermore, the best leaders and companies are always on the lookout for star talent.

\section{Building on Your Current Mix of Skills}

So let's look at what you need to do to take charge of your own career and plan for your success. Essentially, you'll have to be your own career coach. While many hospitality organizations plan for management succession and create strong management-training programs-such as Shangri-La Hotels and Resorts, Hilton International, and Fairmont Hotels and Resorts, to name a few-many other hospitality organizations have less organized programs, particularly for new hires. Managers often find they have been forgotten in their operational roles or possibly stalled due to lack of turnover in the upper management ranks. In addition, you could be held back by simply having a boss who fails to promote your human capital to key decision makers or, alternatively, fails to provide you with new 
learning-oriented challenges, regardless of whether they involve a new job and promotion. While many hospitality companies are working to correct these shortcomings, you would still be wise to take charge of developing your own mix of human capital!

\section{The Power of Past Experience}

But before worrying about that big promotion, you first have to get in the door. All companies want to hire people with the right knowledge, skills, and abilities. Often, however, they don't know exactly what this actually looks like in practice and particularly whether you, as an applicant, have the right mix. You'll certainly have an interview, but research shows that interviews are typically unreliable selection devices. From the manager's point of view, interviews often yield little information that can adequately predict an applicant's potential performance. From your point of view as an applicant, it is difficult to demonstrate your abilities in an interview. As a result, many companies rely heavily on past work experience.

The premise behind assessing work experience is simply that past performance is one of the best predictors of future success, particularly for entry-level jobs. ${ }^{7}$ Hospitality-based experience signals that you know how to handle crucial customer interactions, a cornerstone of successful service-based companies. Additionally, companies pay more for employees who come from similar businesses, and less for individuals who are switching industries. ${ }^{8}$ Thus, your resume acts as a proxy for the "compatibility" of your previous job experience with a potential new job. ${ }^{9}$

Since companies are looking for job experience, you need to show that your background relates well to hospitality. In addition, if you're in the industry and seeking a job with greater responsibilities, you need to demonstrate that your experience has made you ready for this position. Here's how to demonstrate your suitability. If you do not have experience within the hospitality industry, you need to redefine your human capital in terms of the requirements needed for the job in which you are interested. That means that you should determine the knowledge, skills, and abilities that are likely required to perform the job well. Look closely at that job description (or similar ones) for ideas on the specific knowledge, skills, and abilities you need to demonstrate. Then, describe how your work experiences show that you have the necessary human capital. This is true whether or not you've previously worked in the hospitality industry.

Think about the competencies required for the job (or promotion), and match them against the ones you had to develop in your past jobs. The tasks may be different, but the competencies may be similar. Your experience from both inside and outside of the industry may provide you with the requisite 
experience for a host of positions within the hospitality industry. In short, you need to position your mix of human capital as exactly what a potential employer currently desires.

\section{Developing Your Unique Human Capital}

Once you have identified your human capital mix and have found the right industry-related job, you need to convince your potential employer how an investment in you will pay off. But you also need to be thinking about what you will obtain from this job that will help develop your own human capital and enhance your career. What this means is that you should view your job as a "resource-exchange." In essence, in addition to financial compensation, you are trading your knowledge, skills, and abilities in exchange for work experience or opportunities to develop your tool kit of portable human capital. Savvy employees identify learning opportunities within their current jobs that will enhance their human capital and increase marketability within their chosen fields. When the job no longer meets their criteria, they find new opportunities within the company or quite possibly, at competing organizations. They then enter into new exchange relationships. A study of Cornell graduates who had been working in the industry for a number of years revealed the nature of this exchange. ${ }^{10}$ As one respondent commented, "[I'm looking for] building transferable skills using cutting-edge methodologies."

Thus, in managing your own career, we suggest you seek out organizations that provide opportunities to perform work that is meaningful to you. This concept is called a "protean career," in reference to the Greek god Proteus, who could alter his shape at will. ${ }^{11}$ It is also called a "boundaryless career," suggesting that careers cross over multiple organizations and effectively "zigzag" rather than proceed in a linear manner within one organization or even job type. ${ }^{12}$ Research suggests that those who manage their own careers will likely seek out companies that offer the following: (1) intrinsically challenging work that provides individuals opportunities to learn and grow; (2) learning-oriented relationships with colleagues, supervisors, and clients; and (3) the opportunity to obtain valued extrinsic rewards in exchange for the work performed. The first two job features enable you to develop your human capital mix. The third affords you the opportunity to earn a living and live your desired lifestyle.

\section{Look for Challenging Work}

Intrinsically challenging work enables you to acquire and apply new knowledge and skills. You can acquire this form of work in a variety of ways, including participating in special project groups, attending formal and informal training sessions, and accepting opportunities to lead others and direct the department's activities. Those who manage their own careers seek continuously challenging work 
because this type of work enables them to develop and apply such skills as problem-solving, broadpicture visioning, and long- and short-range planning, as well as refine their interpersonal skills. The Cornell study repeatedly returned to this theme. When asked what they are looking for from their employer, respondents offer such ideas as "constantly being challenged and encouraged to explore beyond boundaries" and "learn new things to make myself a better person professionally and personally." The good news for you is that seeking out intrinsically challenging work makes you a productive organizational member, as well as increases your own marketability. In essence, you become more valuable to your own organization and the industry, as well as on the job market.

Fortunately, the structure of the hospitality industry provides many opportunities to gam experience at various levels and aspects of the industry. From a career perspective, this means that human capital growth opportunities exist at the property, corporate chain, regional chain, and ownership companies, as well as the nonhospitality firms that serve them. In the United States, for example, over 70 percent of the 50,000 larger hotel properties are members of chains. Similarly, while the restaurant industry has many more nonchain properties than the hotel industry, restaurant firms still offer multilevel employment opportunities. In the United States, there are over 33,500 establishments that are part of chains. Furthermore, both independent and chain establishments and both hotels and restaurants are served by other companies, some of which have human capital requirements that are similar to those in the hospitality industry. Thus, you should find numerous opportunities to learn and grow in the hospitality industry.

\section{Develop Learning-Oriented Relationships}

Learning-oriented relationships refer to your developing meaningful connections with others at work, such that you capitalize on acquiring new knowledge and skills. ${ }^{13}$ You can form connections with other colleagues, superiors, subordinates, and clients. If you create these types of relationships, you likely will learn more from your personal interactions than you would if you were solely focused on your job tasks. These relationships are built on the notion that you learn best through dialogue with others, and they provide you opportunities to broaden your knowledge base, refine your skills, and obtain feedback on your performance. Learning-oriented relationships are characterized by their reciprocity, meaning that both parties in the relationship contribute to the other's learning, as well as remain open to examine the ways in which they, too, can change and grow. ${ }^{14}$ Whether it be through creating a trusting relationship with a manager, subordinate, or client, we suggest that if you focus on learning 
from others in the process of doing your own job (and completing your own work), you will increase your own knowledge and skills and your own job marketability.

In addition, beyond employer-specific relationship-building opportunities, the hospitality industry has a number of professional associations that can assist with your networking and human capital growth. Some examples are American Hotel and Lodging Association, International Hotel and Restaurant Association, and Hotel Sales and Marketing Association International, as well as local associations such as the Greater Philadelphia Hotel Association, the Nevada Hotel and Lodging Association, and the Hotel Association of New York City.

\section{Pay Attention to the Net Return of Extrinsic Rewards}

In a reciprocal framework, individuals who manage their careers view their jobs as exchange relationships with their employers. This means that instead of trading job security for loyalty to the organization, they trade their skills for compensation, including salaries and benefits. ${ }^{15}$ The mind-set of those who are managing their own careers is a "fair day's work for a fair day's pay," ${ }^{16}$ and these individuals seek out organizations that offer the highest extrinsic net return in exchange for the work they do. Compensation, however, does not refer to just money. It can include job perks, benefits packages, learning opportunities, and even flexible work schedules. Thus, compensation refers to just about any job feature that is important to you.

For example, if you need a flexible work schedule to meet your family needs, part of the exchange framework you create with your employer would include this form of compensation. As one respondent in the Cornell study replied, "It is important that I have my 'Life in Balance.' I never want to look back at my career and feel that it got in the way of my family life and enjoying life in general. My career is a part of my life; it is integrated well into my life."

Smart organizations have figured out ways to make the lifestyles of their employees easier, and keep them on as committed employees. Marriott Corporation, for example, makes a concerted effort to meet the flexible working needs of its employees and even offers them opportunities to develop into franchise owners. ${ }^{17}$ Wyndham Hotels offers its female employees support, mentoring, and career advice through its Wyndham on Their Way program for associates. ${ }^{18}$ The SAS Institute offers its employees competitive pay and enhances this pay with attractive job features such as on-site health care, workout gyms, a golf course, a community pool, a Montessori school, dry cleaning, and even a post office. ${ }^{19}$ These employers want to make the lifestyles and work experiences of their employees as easy and seamless as possible, so that these employees will never want to leave their organization. This is the 
contemporary careers model in operation: companies determine the job features that induce line staff and managers to enter into and remain in a resource exchange with them.

In this exchange framework, you would view yourself as almost a contingent "in-house temporary worker." Your anticipated time with your company is essentially indefinite (or to be

determined). ${ }^{20}$ You would continuously weigh the net return or costs and benefits associated with your current job against other potential opportunities. As long as you continue to receive the specific rewards that are valuable to you-in exchange for working hard and well-you will be more likely to remain in your current organization and develop yourself within that company.

\section{You as a Leader}

As you move up the hospitality career ladder, you are increasingly likely to have greater managerial and leadership responsibilities, and these responsibilities begin with your learning how to supervise others. However, having the responsibility for managing others does not ensure that you will be an effective leader. In part, leadership is a human capital capability that has to be learned and practiced, and managing is different from leading. Nonetheless, placing yourself in the position to have such responsibility, directly or through special group assignments, is critical to reaching higher hospitality career levels.

Let's compare the roles of a manager and of a leader. Managers are often required to budget, plan, and solve problems. In other words, a manager's job often involves maintaining the status quo. Successful leaders, however, often must shake up the status quo. Leaders push their team to continuously improve through setting a vision, communicating that vision, and encouraging others by empowering them to act and meeting their motivational needs. ${ }^{21}$ The difference is that managers control-and leaders change. Managers enact a plan-and leaders create a new one. So, the natural question is: How can new managers simultaneously be effective leaders and find jobs that will enable them to develop their leadership knowledge and skills?

As you take on various managerial jobs within the industry, look for ways to develop your human capital mix that will strengthen your leadership skills. One thing you will notice is that many of the skills required to be an effective manager are different from the skills required to be a successful leader. As a result, managers can have leadership responsibilities but not perform them well. Alternatively, they can also have no direct supervisory responsibility but exercise leadership every day, for example, as a team leader of a project group. The important point is that, if you wish to advance in the hospitality industry, you need to develop and hone this critical human capital skill. Indeed, it is for 
this reason that the Cornell School of Hotel Administration's mission is not about hospitality management but, rather, hospitality leadership. Thus, while you will learn more about developing yourself as a leader later in this book (Chapter 6), any discussion of career planning must consider what you need to do to become a future leader.

Leadership skills are crucial to advancement in the hospitality industry. One study that examined competencies required for country club managers identified a list of skills that included budgeting, financial analysis, communication skills, and time management. ${ }^{22} \mathrm{~A}$ second study examined competencies required for hospitality management jobs, whether in rooms or food and beverage. Not surprisingly, both studies found that in the context of managing an operation, leadership skills are paramount. ${ }^{23}$ However, these studies also found that certain types of leadership skills are more crucial than others. Whether you are a brand new hospitality manager or a seasoned executive- level leader, research suggests you'll need a mix of technical know-how, interpersonal savvy or emotional intelligence, and conceptual and analytic skills. ${ }^{24}$ If you are a line-level manager, technical skills are paramount. So, if you become the front-desk manager, you'd best know the check-in process; if your new post is at a food and beverage outlet, you should have a good understanding of the ins and outs of the order-placing system (among other functions; see Chapter 16). Rather than rely on your conceptual and analytic skills, you need to be able to pay attention to the operation and spot and correct problems, even before they occur. It's a challenging job.

In contrast to technical knowledge, leaders need conceptual and analytic skills. Leaders need to perform the strategic planning necessary for the company's long-term health. Although leaders usually have technical expertise, that's not their focus. For example, a general manager's job involves applying his or her reasoning, inductive thinking, and planning skills. While it is certainly important that a general manager understands the roles of his or her subordinates, and definitely not be ignorant of their job tasks, it is less critical for the general manager to have specific technical expertise. Even if they are technically skilled in their subordinates' jobs, top managers must be willing to let their subordinates perform their tasks and not micromanage.

Interestingly, interpersonal skills, or emotional intelligence, are equally important at all levels of management. This includes the ability to understand one's strengths and weaknesses, maintain emotional self-control, relate to and convey empathy to others, assess the political layout of any given group, and (especially important) motivate others through developing work relationships. ${ }^{25}$

Certainly, you need to have the technical expertise to perform your job well, but you also must think about ways to strengthen how you interact with your subordinates, bosses, peers, and clients, 
especially when there are differing opinions. This often involves carefully listening to others (see the next chapter). ${ }^{26}$ The good news is that you can work on your emotional intelligence and interpersonal skills at any age.

Specific Skills for Strong Leaders

Looking at the essential conceptual and analytic skills for your human capital leadership mix, we see a growing consensus that successful leaders must do three crucial things in their jobs: sense making, visioning, and being inventive. ${ }^{27}$ Sense making refers to the ability to read and understand one's operating environment and map a plan to operate within it. Those strong in sense making have a good handle on the context in which their business operates and are ready to adjust to unexpected outside forces, such as economic pressures, new competition, or a shift in customer needs. These leaders can handle the complexities of multiple operational pressures, and they are strong at mapping out and explaining a plan of action. They also understand that sense making is an iterative process and that the plan needs to be continuously refined. These individuals are also good at listening to and incorporating multiple viewpoints and perspectives into their frameworks. One only has to think of a strong hotel or restaurant general manager who adjusts the plan to shifting price-sensitive markets and a stalling economy to see what this might look like in practice. This type of leader would also be skilled at soliciting and incorporating the input of many individuals as he or she prepares a continuously revised business plan.

\section{J. W. (Bill) Marriott, Cornell Icon of Industry}

In recent years, the School of Hotel Administration has presented the Cornell Icon of the Industry Award. The award recognizes the accomplishments of outstanding leaders in the hospitality industry on the basis of lifetime achievements in the hospitality industry and contributions to their community or society. The winner in 2010 was J. W. (Bill) Marriott. He exemplifies leadership in hospitality.

J. W. (Bill) Marriott, Jr., is the chairman and chief executive officer of Marriott International, Inc. He began his hospitality career working for his father's Hot Shoppes restaurant chain during his high school and college years. He joined the company full time in 1956. Just eight months later, Marriott took over the company's hotel operations, shortly after 
the Twin Bridges Motor Hotel, Marriott's first venture into the lodging industry, opened in Washington, D.C.

Under Marriott's leadership, Marriott International has grown from a family restaurant business to a global lodging company with more than 3,100 properties in 66 countries and territories. Known for its commitment to diversity, social responsibility, and community engagement, the firm is consistently recognized among the most admired companies. Marriott has also worked to compile a family of 18 lodging brands that range from limited-service to full-service luxury hotels. The company manages and franchises hotels and resorts under these brand names: Marriott, JW Marriott, Renaissance, Bulgari, Ritz-Carlton, Courtyard, Residence Inn, SpringHill Suites, TownePlace Suites, and Fairfield Inn. It operates vacation ownership resorts under these flags: Marriott Vacation Club International, Ritz-Carlton Club, and Grand Residences by Marriott. The company also operates Marriott Executive Apartments, provides furnished corporate housing through its Marriott ExecuStay division, operates conference centers, and manages golf courses.

In addition to his work at Marriott International, Marriott serves his country and world as a leader and philanthropist. He is on the board of the J. Willard \& Alice S. Marriott (Charitable) Foundation. He is a member of the National Business Council and the Executive Committee of the World Travel \& Tourism Council. He also serves as the chairman of the Mayo Clinic Capital Campaign. Marriott recently served as chairman of the President's Export Council and member of the Secure Borders Open Doors Advisory Committee and the U.S. Travel and Tourism Advisory Board.

Visioning refers to the ability to create a captivating future image of the organization. Those who vision well are able to lay out what the organization could and should become, given its purpose and competitive strength. These leaders are able to picture what the future could look like, and they invite others to contribute to and share in this image. Thus, they generate excitement around their ideas and they give people a sense of purpose to their work. They energize a group through identifying a collective set of possibilities. An example of a leader who demonstrates this type of skill is Herb Kelleher at Southwest Airlines. He was able to successfully create and sustain such an energized, customerfocused service culture that the company has earned profits for 37 consecutive years. ${ }^{28}$

Finally, successful leaders are inventive. This means that they are skillful in implementing the vision. This type of skill involves translating broad ideas into a specific action plan. It requires one to 
think in both abstract terms and concrete details. Mapping out an action plan, though, isn't just about working through detailed steps. It also requires one to think creatively about new ways of working-and organizing the work of others. That is, it can involve reinventing how the business works and the ways in which people carry out the organization's goals. Those strong at inventing are willing to explore alternative and sometimes nontraditional options to refraining work. Human resource executives at Hilton Garden Inn, for example, are using a Playstation-based virtual gaming experience to competitively teach their employees about guest service. They link their training directly to their guest comment system and, in doing so, have redesigned the ways in which they develop their staff. ${ }^{29}$

As you can see, these three analytic skills are related to one another, and woven through them are the crucial interpersonal skills of inspiring, involving, and mobilizing a workforce. Yet, it is also important to remember that no leader can be all things to all people. Successful leaders determine their key strengths in these conceptual areas, and they surround themselves with others who complement their skill sets. ${ }^{30}$ Thus, you should not be deterred if these three analytic skills seem daunting to develop and simultaneously enact.

The crucial question to consider at this point is that if sense making, visioning, and inventing-as well as your degree of emotional intelligence- represent a human capital knowledge and skill set central to your success as a hospitality leader, how do you go about finding the managerial jobs that will provide the necessary opportunities to learn these skills? In addition, how do you ensure that while you gain the technical expertise to do your $\mathrm{j}$ o $\mathrm{b}$ well, you also learn how to apply leadership skills to enact continuous improvement? After all, as mentioned at the beginning of this chapter, your work experience is reflective of your human capital and central to your ability to meet your career goals. Until you get to that leadership position, you can take advantage of the multiple-layer structure of the hospitality industry to give you leadership opportunities at the property, regional, and corporate (chain) levels. Here's how to manage your career for leadership.

\section{What to do Today}

To begin with, you should search out a job and company that help you add to your leadership tool kit and progress in meeting your career goals. There are subtle, yet important, things to think about in the process. Needless to say, you need to build your credibility by doing your job well. Beyond accomplishing your job tasks, this means being an active self-leader. Research tells us that great leaders (who also make great followers) are self-starters who show their own initiative ${ }^{31}$ They assume responsibility for influencing their own performance and even are willing to do nonmotivating work-for 
a while. Using their emotional intelligence, they are aware of their feelings and attitudes about their work, and they act nondefensively and even -welcome developmental feedback and advice. They also seek out their opportunities to learn and grow, using their job as a base from which to work. In addition, they develop solid relationships with their bosses. They regularly keep their bosses updated on their progress - or perhaps even lack thereof on a particular task-and are well aware of how their efforts and results fit into the bigger picture. They are also aware of how others in a team might depend on their performance, and they manage these expectations in positive ways. Finally, future leaders challenge the status quo in a positive manner.

\title{
Making Career Decisions-Three Simple Criteria
}

\author{
John Longstreet \\ President and CEO \\ Quaker Steak \& Lube
}

To be sure, making a good career decision will have a huge impact on your life, perhaps only second to your choice of a spouse. Studies have shown that one of the top two factors considered in staying with a job is one's supervisor. So should it be the first and foremost consideration in taking a job. Like choosing a mate, your boss must be someone you respect and believe in as a proven leader and, most of all, a person you trust.

Success at work clearly can be attributed to performance, but it is also heavily influenced by your supervisor. Your boss needs to be someone from whom you can learn, who will give you authority, and, most of all, someone who will credit your accomplishments. Think of this person as your representative to upper management. Will they represent you fairly?

So, absolutely the most important consideration in taking a job is your boss. Nearly as essential as selecting your boss is making sure that there is a good fit with the other people with whom you will be working. In the hospitality business, it's all about people. The selection of a company is also all about people.

Another consideration is the economic vitality of the company. Sometimes even the best people cannot overcome a bad balance sheet. And make sure that the company values mirror your own.

Many people make career decisions based on the actual job. This may be the least important of the considerations. For most, especially those who are success oriented, the time 
spent in a particular job will be relatively short and thus should not be the basis of a career decision. It is important only in that the job must be one where success can be achieved and that provides a step to greater opportunity. And, by the way, when in the job, focus on being successful in that position, do not fixate on the next position, or you may never achieve it. Also, do not get hung up by money. If you choose a job in which you can succeed, in a company that is sound, and with a good boss, the money will come.

In summary, determine that the company's financial situation and its values are sound. Make sure the job is one in which you can achieve success and that provides upward mobility. And, most importantly, get to know the people-especially your boss. If the company fails in any one of these three criteria, you should pass.

If you engage in these practices and lead yourself well, you will garner the cachet to manage your career more actively. The next step in this process is to find companies whose executive-team leaders are seeking out, training, and developing new leaders who will one day take over their own jobs. These are leaders who will provide you with the opportunity to enhance your tool kit of interpersonal, conceptual, and analytic skills. Look for executive-team leaders who themselves have the appropriate skills, who will help you develop and take on increasingly challenging tasks, and who actually will let you assume responsibility for those tasks. ${ }^{32}$ Ask questions about the path of those who have preceded you and the opportunities these managers were and were not given. Ask your prospective manager to tell you about former subordinates that he or she has developed, and where they went in the industry. If answers are not forthcoming, you probably want to look for a better opportunity. In addition, seek out executive-team members who can communicate well and act as trustworthy leaders to the managers they supervise. These are the bosses who will provide you with challenge and learning in your work and, as a result, enable you to successfully develop your own unique mix of human capital.

Next, inquire about the specific career paths managers can take within the organization you're considering. Ask potential bosses to outline a possible career path for you, and ask them to commit to regularly revisiting progress. This path could indicate possible jobs, as well as the expected, finite time frame for each position. Map out how these potential jobs enable you to gain important knowledge and develop crucial skills relevant to your career goals. In addition, ask your boss to show you how today's job represents learning opportunities that will prepare you for greater future challenges with increased responsibilities. Also, if relevant, let your boss know whether you are willing to relocate or even make a lateral move to advance your career, while simultaneously contributing to your organization. 
The final key to this process is to remain open and flexible. Many opportunities present themselves that were not part of the "original plan." Yet these unexpected jobs may be exactly what you need to develop and strengthen your human capital. So if a job is not ideal (and no job is perfect), consider whether it can be reframed in ways that meet your needs. If a company is not one you would initially consider, look for opportunities present in the job itself. Alternatively, if both a job and an organization are not exciting to you, consider if you would be working for a strong leader who can provide you with opportunities to grow that go beyond the defined job description. As you consider every opportunity, remember that the goal is to manage your career in ways that will provide you with the human capital mix central to your success-a success that you define.

${ }^{1}$ C. A. Enz, "What Keeps You Up at Night? Key Issues of Concern for Lodging Managers," Cornell Hotel and Restaurant Administration Quarterly 42 (2001): 38-45; and C. A. Enz, "Issues of Concern for Restaurant Owners and Managers," Cornell Hotel and Restaurant Administration Quarterly 45 (2004): 315-332.

${ }^{2}$ G. S. Becker, "Investment in Human Capital," Journal of Political Economy 70 (1962): 9-49; and M. A. Hitt, L. Bierman, K. Shimizu, and R. Kochgar, "Direct and Moderating Effects of Human Capital on Strategy and Performance in Professional Firms: A Resource-Based Perspective: Academy of Management Journal 44 (2001): 1328.

${ }^{3}$ U.S. Dept. of Commerce, www.bls.gov/oco/cg/cgs036.htm; www.bls.gov/oco/ cg/cgs023.htm.

${ }^{4}$ M. C. Sturman and B. Carroll, "The Job Compatibility Index: A New Approach to Defining the Hospitality Labor Market," Center for Hospitality Report 9 (2009): 1.

${ }^{5}$ T. Hinkin and J. B. Tracey, "What Makes It So Great? An Analysis of Human Resources Practices among Fortune's Best Companies to Work For," Cornell Hospitality Quarterly 51(2) (2010): 158-170.

${ }^{6}$ U.S. Dept. of Commerce, "Forward Forecast of Employment in Hospitality," www.bls.gov/oco/cg/cgs036.htm\#emply.

${ }^{7}$ M. C. Sturman, "Searching for the Inverted U-Shaped Relationship between Time and Performance: Metaanalyses of the Experience/Performance, Tenure/ Performance, and Age/Performance Relationships," Journal of Management 29 (2003): 609-640.

${ }^{8}$ M. C. Sturman, K. Walsh, and R. A. Cheramie, "The Value of Human Capital Specificity versus Transferability, "Journal of Management 34 (2008): 290-316.

${ }^{9}$ R. E. Ployhart, B. Schneider, and N. Schmitt, Staffing Organizations, 3rd ed. (Mahwah, NJ: Erlbaum, 2006).

${ }^{10} \mathrm{~K}$. Walsh and M. S. Taylor, "Developing In-House Careers and Retaining Management Talent: What Hospitality Professionals Want from Their Jobs," Cornell Hospitality Quarterly 48 (2007): 163-182.

${ }_{11}$ D. T Hall, "Protean Careers of the 21st Century," Academy of Management Executive 10 (1996): 8-16.

${ }^{12}$ M. B. Arthur and D. M. Rousseau, The Boundaryless Career: A New Employment Principle for a New Organizational Era (New York: Oxford University Press, 1996).

${ }_{13} \mathrm{~J}$. K. Fletcher, "A Relational Approach to the Protean Worker. In D. T. Hall, ed. The Career Is Dead-Long Live the Career (San Francisco: Jossey-Bass, 1996), 105-131; D. T Hall, Careers in and out of Organizations (Thousand Oaks, CA: Sage, 2002); and K. E. Kram, and D. T Hall, Mentoring in the Context of Diversity and Turbulence. In E. E. Kossek and S. A. Lobel, eds. Managing Diversity: Human Resource Strategies for Transforming the Workplace (Cambridge, MA: Blackwell, 1996), 108-136.

${ }^{14}$ Fletcher, 1996.

${ }^{15}$ M. A. Cavanaugh and R. A. Noe, "Antecedents and Consequences of Relational Components of the New Psychological Contract," Journal of Organizational Behavior 20 (1999): 323-340; S. L. Robinson and D. M. Rousseau, "Violating the Psychological Contract: Not the Exception but the Norm," Journal of Organizational Behavior 15 (1994): 245-259; and S. E. Sullivan, "The Changing Nature of Careers: A Research Agenda," Journal of Management 25 (1999): 457-484. 
${ }^{16}$ D. M. Rousseau and K. A.Wade-Benezoni, "Linking Strategy and Human Resource Practices: How Employee and Customer Contracts Are Created," Human Resource Management 33 (1994): 463-489.

${ }^{17}$ www.Marriott.com.

${ }^{18}$ www.wyndham.com.

${ }^{19}$ C. A. O'Reilly and J. Pfeffer, Hidden Value: How Great Companies Achieve Extraordinary Results with Ordinary People (Boston, MA: Harvard Business School Press, 2000).

${ }^{20}$ J. McLean Parks, D. Kidder, and D. G. Gallagher, "Fitting Square Pegs into Round Holes: Mapping the Domain of Contingent Work Arrangements onto the Psychological Contract," Journal of Organizational Behavior 19 (1998): 697-730; S. E. Sullivan, W. A. Carden, and D. F. Martin, "Careers in the Next Millennium: Directions for Future Research," Human Resource Management Review 8 (1998): 165-185.

${ }^{21}$ J. P. Kotter, "What Leaders Really Do," Harvard Business Review 68 (1990): 103-111.

22 J. Perdue, R. Woods, and J. Ninemeier, "Competencies Required for Future Club Managers' Success," Cornell Hospitality Quarterly 42 (2001): $60-65$.

${ }^{23}$ C. Kay and J. Russette, "Hospitality-Management Competencies," Cornell Hospitality Quarterly 41 (2000): 52-63.

${ }^{24}$ Kotter, 1990.

${ }^{25}$ D. Goleman, "What Makes a Leader?" Harvard Business Review 82 (2004): 1-10.

${ }^{26}$ D. Ancona, T. W. Malone, W.J. Orlikowski, and P. M. Senge, "In Praise of the Incomplete Leader," Harvard Business Review (February 2007): 1-8.

${ }^{27}$ Ibid.

${ }^{28}$ Southwest Airlines, 2009 Annual Report.

29 "Hilton Garden Inn Officially Launches Innovative Training Using PSP," BusinessWire (January 14, 2009); see also C.A. Enz, K. Walsh, R. Verma, S.E. Kimes, and J. Siguaw, "Cases in Innovative Cases in Hospitality and Related Services, Set 4," Cornell University School of Hotel Administration Center for Hospitality Research Report. (July 2010).

${ }^{30}$ Ancona et al., 2007.

${ }^{31}$ C. C. Manz and H. P. Sims, "Leading Workers to Lead Themselves: The External Leadership of Self-Managing Work Teams," Administrative Science Quarterly 32 (1987): 106-128.

${ }^{32}$ Walsh and Taylor, 2007. 